Johannes Hofland

Jan Bakker

Richard A. Feelders

\section{What's new on the HPA axis?}

Received: 24 February 2015

Accepted: 22 March 2015

Published online: 8 April 2015

(C) The Author(s) 2015. This article is published with open access at Springerlink.com

\section{J. Hofland ( ) - R. A. Feelders}

Section of Endocrinology, Department of Internal Medicine, Erasmus Medical Center, Rotterdam, The Netherlands e-mail: j.hofland@erasmusmc.nl

\section{J. Bakker}

Department of Intensive Care-Adults, Erasmus Medical Center, Rotterdam, The Netherlands

\section{Introduction}

The human body depends on an integrated neuro-endocrine response in order to adapt to external and internal stressors. In critical illness this stress response coordinates endocrine, neural, cardiovascular and immune systems with the aim to maximize survival chances. The hypothalamus-pituitary-adrenal (HPA) axis, which also includes elements producing the neurohypophysial hormone arginine-vasopressin (AVP), is one the key effectors within this system [1]. Relative HPA or AVP deficiency contributes to cardiovascular collapse in critically ill patients, leading to the rationale of therapy with these hormones in shock. Recent developments have implicated copeptin, a by-product of the AVP precursor, as a novel biomarker for early stages of critical illness that could influence clinical decision-making.

\section{Physiology of the HPA axis}

A wide variety of circulating local and neurosensory signals control hypothalamic corticotrophic-releasing hormone (CRH) and AVP release from the paraventricular nucleus (PVN). Parvocellular neurons co-secrete $\mathrm{CRH}$ and AVP into the hypophysial portal circulation. These peptides reach the adenohypophysis and synergistically stimulate the release of adrenocorticotrophic hormone (ACTH). ACTH increases adrenocortical production and the release of cortisol, the main glucocorticoid in humans with widespread homeostatic effects in many organs. In a recent elegant study, Boonen et al. demonstrated that elevated cortisol levels in critical illness result from a reduced cortisol metabolism [2] despite suppressed ACTH and cortisol pulse secretion [3].

AVP is also produced in the magnocellular neurons of the PVN and directly secreted into the bloodstream through their axons in the posterior pituitary (Fig. 1a). The principal effects of circulating AVP are vasoconstriction through its V1a receptor in vascular smooth muscle cells and water conservation through renal V2 receptors.

\section{Biomarkers of AVP system}

As a stress marker, levels of AVP show a bi-phasic response during disease, with an initial rise depending on disease severity and subsequent decrease. Implementation of AVP measurements for clinical decision-making in patients has been hampered by the stability of the peptide, its binding to platelets and its short half-life of $24 \mathrm{~min}$. The nonapeptide AVP is cleaved from its precursor preprovasopressin together with neurophysin II and copeptin (Fig. 1b). Copeptin is a glycopeptide with an obscure function which constitutes the C-terminal 39 amino acids of preprovasopressin and demonstrates significant stability ex vivo and even post-mortem [4, 5]. The development of a one-step sandwich immunoassay for copeptin has provided the tool for an increasing number of studies over the last decade into the use of this AVP 
Fig. 1 a Schematic overview of the hypothalamus-pituitaryadrenal $(H P A)$ axis and arginine-vasopressin $(A V P)$. Co-secreted corticotrophicreleasing hormone $(\mathrm{CRH})$ and AVP from the parvocellular $(P)$ cells of the paraventricular nucleus stimulate pituitary release of adrenocorticotrophic hormone $(A C T H)$, which in turn induces cortisol secretion from the adrenal. Hypothalamic magnocellular $(M)$ neurons transport AVP through their axons to the posterior pituitary where AVP is secreted in response to osmotic or hemodynamic stimuli. b Precursor molecule of AVP consisting of four individual peptides
A

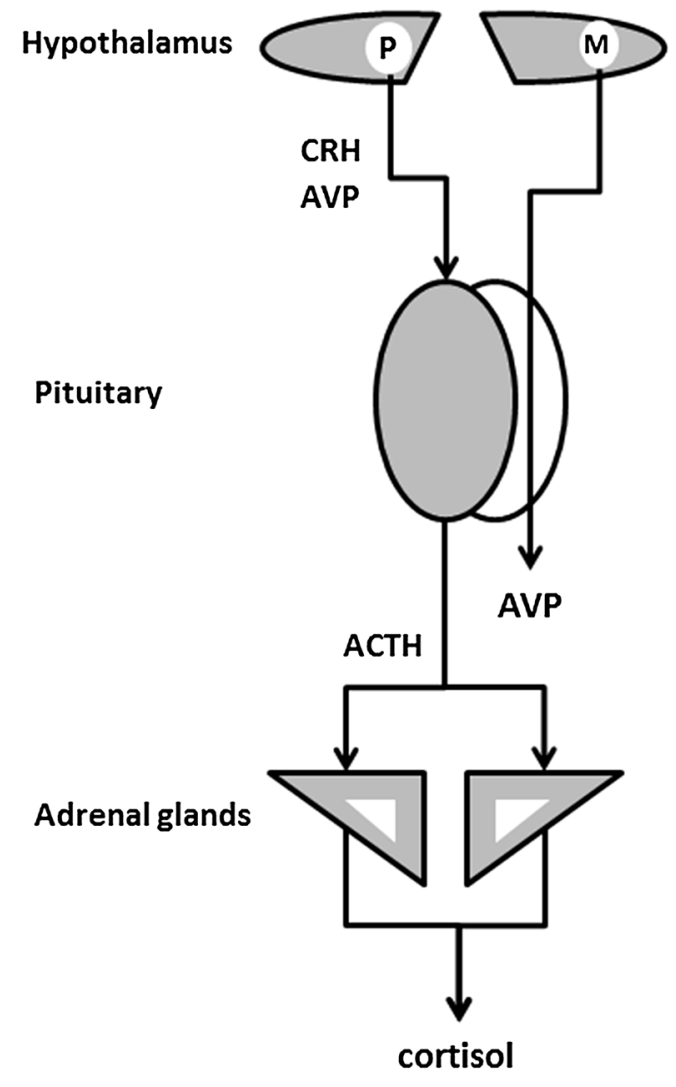

B

Preprovasopressin

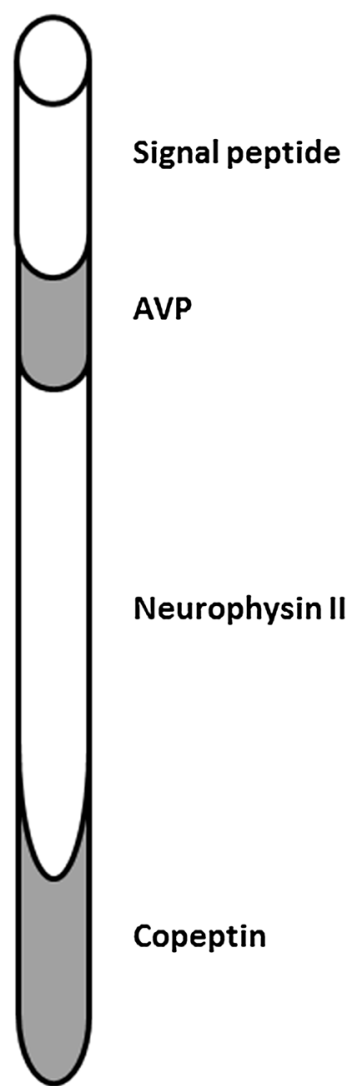

co-secreted peptide as an early marker for osmotic or hemodynamic dysregulation.

First studied in septic shock patients, copeptin levels were found to be $>400$-fold higher in this patient population than in healthy control subjects [5]. Circulating copeptin concentrations are also increased in critically ill patients during early stages of systemic inflammatory response syndrome, myocardial infarction, heart failure, stroke or after major surgery and trauma and are associated with AVP, C-reactive protein and cortisol concentrations, osmolality and disease severity [4, 6-12]. Copeptin levels at presentation are associated with mortality and have been shown to be additive in prediction models of survival in patients with septic shock [7, 8], myocardial infarction [10] and stroke [12]. Moreover, copeptin is superior to AVP as discriminator between septic and non-septic patients [13]. Interestingly, the correlation between AVP and copeptin levels has been found to dissipate in patients on hemofiltration therapy, thereby questioning the reliability of copeptin measurement as an adequate marker of the vasopressinergic system in this patient subgroup [4, 9]. As expected, copeptin level decreases in the majority of patients treated with exogenous AVP [14].
In a recent extensive Chinese study of patients presenting to the emergency department with sepsis [15], copeptin was measured together other stress markers. All markers showed a step-wise increment according to disease severity. In the patient population, copeptin, cortisol and ACTH levels measured at admission were all inversely associated with survival, with copeptin having the highest prognostic value [receiver operating characteristics area under the curve (AUC) of 0.826]. Intriguingly, the combination of copeptin, cortisol and procalcitonin concentrations and the Mortality in Emergency Department Sepsis (MEDS) score yielded an AUC of 0.891 for predicting 28-day survival.

\section{Conclusions}

Copeptin constitutes a novel and promising biomarker during the acute phase for disease severity and prognosis in critically ill patients. Its concentration can distinguish between sepsis and other causes of critical illness and appears a superior marker to AVP. Future studies are needed to delineate whether copeptin measurements are 
cost-effective, add significantly to clinical judgment and can be utilized for stratification of therapy, particularly early management of sepsis.

Conflicts of interest The authors have no potential conflict of interest that could prejudice the impartiality of this scientific work.
Open Access This article is distributed under the terms of the Creative Commons Attribution-NonCommercial 4.0 International License (http://creativecommons.org/licenses/by-nc/4.0/), which permits any noncommercial use, distribution, and reproduction in any medium, provided you give appropriate credit to the original author(s) and the source, provide a link to the Creative Commons license, and indicate if changes were made.

\section{References}

1. Chrousos GP (2000) The stress response and immune function: clinical implications. The 1999 Novera H. Spector Lecture. Ann NY Acad Sci 917:38-67

2. Boonen E, Vervenne H, Meersseman $\mathrm{P}$, Andrew R, Mortier L, Declercq PE, Vanwijngaerden YM, Spriet I, Wouters PJ, Vander Perre S, Langouche L, Vanhorebeek I, Walker BR, Van den Berghe G (2013) Reduced cortisol metabolism during critical illness. N Engl J Med 368:1477-1488

3. Boonen E, Meersseman P, Vervenne H, Meyfroidt G, Guiza F, Wouters PJ, Veldhuis JD, Van den Berghe G (2014) Reduced nocturnal ACTH-driven cortisol secretion during critical illness. Am J Physiol Endocrinol Metab 306:E883-E892

4. Jochberger S, Velik-Salchner C, Mayr VD, Luckner G, Wenzel V, Falkensammer G, Ulmer H, Morgenthaler N, Hasibeder W, Dunser MW (2009) The vasopressin and copeptin response in patients with vasodilatory shock after cardiac surgery: a prospective, controlled study. Intensive Care Med 35:489-497

5. Struck J, Morgenthaler NG, Bergmann A (2005) Copeptin, a stable peptide derived from the vasopressin precursor, is elevated in serum of sepsis patients. Peptides 26:2500-2504

6. Jochberger S, Morgenthaler NG, Mayr VD, Luckner G, Wenzel V, Ulmer H, Schwarz S, Hasibeder WR, Friesenecker BE, Dunser MW (2006) Copeptin and arginine vasopressin concentrations in critically ill patients. J Clin Endocrinol Metab 91:4381-4386
7. Morgenthaler NG, Muller B, Struck J, Bergmann A, Redl H, Christ-Crain M (2007) Copeptin, a stable peptide of the arginine vasopressin precursor, is elevated in hemorrhagic and septic shock. Shock 28:219-226

8. Seligman R, Papassotiriou J, Morgenthaler NG, Meisner M, Teixeira PJ (2008) Copeptin, a novel prognostic biomarker in ventilator-associated pneumonia. Crit Care 12:R11

9. Jochberger S, Zitt M, Luckner G, Mayr VD, Wenzel V, Ulmer H, Morgenthaler NG, Hasibeder WR, Dunser MW (2009) Postoperative vasopressin and copeptin levels in noncardiac surgery patients: a prospective controlled trial. Shock 31:132-138

10. Lipinski MJ, Escarcega RO, D’ Ascenzo F, Magalhaes MA, Baker NC, Torguson R, Chen F, Epstein SE, Miro O, Llorens P, Giannitsis E, Lotze U, Lefebvre S, Sebbane M, Cristol JP, ChenevierGobeaux C, Meune C, Eggers KM, Charpentier S, Twerenbold R, Mueller C, Biondi-Zoccai G, Waksman R (2014) A systematic review and collaborative meta-analysis to determine the incremental value of copeptin for rapid rule-out of acute myocardial infarction. Am J Cardiol 113:1581-1591

11. Westermann I, Dunser MW, Haas T, Jochberger S, Luckner G, Mayr VD, Wenzel V, Stadlbauer KH, Innerhofer $\mathrm{P}$, Morgenthaler N, Hasibeder WR, Voelckel WG (2007) Endogenous vasopressin and copeptin response in multiple trauma patients. Shock 28:644-649
12. De Marchis GM, Katan M, Weck A, Fluri F, Foerch C, Findling O, Schuetz P, Buhl D, El-Koussy M, Gensicke H, Seiler M, Morgenthaler N, Mattle HP, Mueller B, Christ-Crain M, Arnold M (2013) Copeptin adds prognostic information after ischemic stroke: results from the CoRisk study. Neurology 80:1278-1286

13. Lesur O, Roussy JF, Chagnon F, GalloPayet N, Dumaine R, Sarret P, Chraibi A, Chouinard L, Hogue B (2010) Proven infection-related sepsis induces a differential stress response early after ICU admission. Crit Care 14:R131

14. Torgersen C, Luckner G, Morgenthaler NG, Jochberger S, Schmittinger CA, Wenzel V, Hasibeder WR, Grander W, Dunser MW (2010) Plasma copeptin levels before and during exogenous arginine vasopressin infusion in patients with advanced vasodilatory shock. Minerva Anestesiol 76:905-912

15. Zhang Q, Dong G, Zhao X, Wang M, Li CS (2014) Prognostic significance of hypothalamic-pituitary-adrenal axis hormones in early sepsis: a study performed in the emergency department. Intensive Care Med 40:1499-1508 